\title{
АНАТОМИЯ
}

\author{
UDC 617.578
}

\section{The lateral extensor slips (lateral bundles) of the human finger in interphalangeal flexion}

\author{
K. J.van Zwieten ${ }^{1}$, C. Thywissen ${ }^{2}$, A. Hotterbeekx ${ }^{1}$, L. Kosten ${ }^{1}$, S. de Munter ${ }^{1}$, \\ B.S.de Bakker ${ }^{3}$, P.Adriaensens ${ }^{1}$, S. A. Varzin $^{4,5}$, O. E.Piskun ${ }^{5}$, K. P. Schmidt ${ }^{1}$ \\ ${ }^{1}$ University of Hasselt, Bldg. D, Agoralaan, Diepenbeek, B 3590, Belgium \\ ${ }^{2}$ Jessa Hospital (Jessa Ziekenhuis, campus Virga Jesse), 11, Stadsomvaart, Hasselt, 3500, Belgium \\ ${ }^{3}$ University of Amsterdam, 15, Meibergdreef, Amsterdam, 1105 AZ, The Netherlands \\ ${ }^{4}$ St. Petersburg State University, 7-9, Universitetskaya nab., St. Petersburg, 199034, Russian Federation \\ ${ }^{5}$ Peter-the-Great St. Petersburg Polytechnic University, 29, Politekhnicheskaya ul., St. Petersburg, 195251, \\ Russian Federation
}

For citation: van Zwieten K. J., Thywissen C., Hotterbeekx A., Kosten L., de Munter S., de Bakker B. S., Adriaensens P., Varzin S. A., Piskun O.E., Schmidt K. P. The lateral extensor slips (lateral bundles) of the human finger in interphalangeal flexion. Vestnik of Saint Petersburg University. Medicine, 2018, vol.13, issue 1, pp. 46-57. https://doi.org/10.21638/11701/spbu11.2018.105

In the present paper on functional anatomy of the human finger, we discuss the normal palmar gliding of the lateral slips (or lateral bundles) of the extensor tendon along the flexing proximal interphalangeal (PIP) joint. Finely tuned by the tendinous spiral fibers, this palmar gliding enables simultaneous flexion of the distal interphalangeal (DIP) joint. This is essential for undisturbed kinematic coupling of finger motion. In-vitro observations during manipulation of anatomical specimens of the finger reveal this phenomenon. In-vivo observations, however, have hitherto been absent. By means of high-resolution ultrasonography, we thus obtained in-vivo transversal sections of the PIP joint in extension as well as in flexion showing the palmar gliding of the lateral bundles. The images were used to compare with equivalent in-vitro transversal sections, and with current models from literature. We observed a satisfying congruence between our transverse images acquired by high-resolution MRI and by highresolution ultrasonography. Proximal interphalangeal flexion alone shows that the lateral bundles assume only slightly more palmar positions than in extension. In subsequent distal interphalangeal flexion however, the lateral bundles assume almost sagittal positions, and as a consequence, also more palmar positions along the proximal interphalangeal joint. The resulting data may contribute to finger extensor tendon repair by reconstructive surgery techniques.

Keywords: lateral extensors (lateral bundles) of a human finger, movements, an extension in an interfalangeal joint, PIP, DIP, the functional anatomy of a finger, a finger, a hand, an interfalangeal joint, the top extremity, sliding of side bunches, high-res MRT, a high-res ultrasonografy.

() Санкт-Петербургский государственный университет, 2018 


\section{Introduction, State of the art}

In-vivo data about the precise positions of the tendinous lateral slips (also known as lateral bands or lateral bundles) of the extensor assembly of the human finger in proximal interphalangeal (PIP) flexion, prior to or simultaneous with distal interphalangeal (DIP) flexion, remain remarkably scarce $[1 ; 2 ; 3]$. During flexion of the PIP joint, these lateral bundles glide from dorsal positions to more palmar positions [4; 5]. This phenomenon also determines structurally the possibility of the DIP joint to be flexed not only subsequently, but also simultaneously. It is so one of the prominent key features of the kinematic coordination of both interphalangeal joints of the finger, and - in a broader sense of the whole hand [6]. The abovementioned palmar gliding of the lateral bundles, finely tuned thanks to the guidance of the suspending spiral fibers, occurs along the bony and the ligamentous contours of the flexing PIP joint [6;7]. These changing contours of this joint during its flexion were recently described by us $[7 ; 8]$.

Embryological, respectively fetal data of the developing PIP joint greatly help to understand its definitive structure (see figs. $1 a, 1 b$ ). These figures are in good accordance with current concepts of interphalangeal joint morphogenesis in particular [9-11].
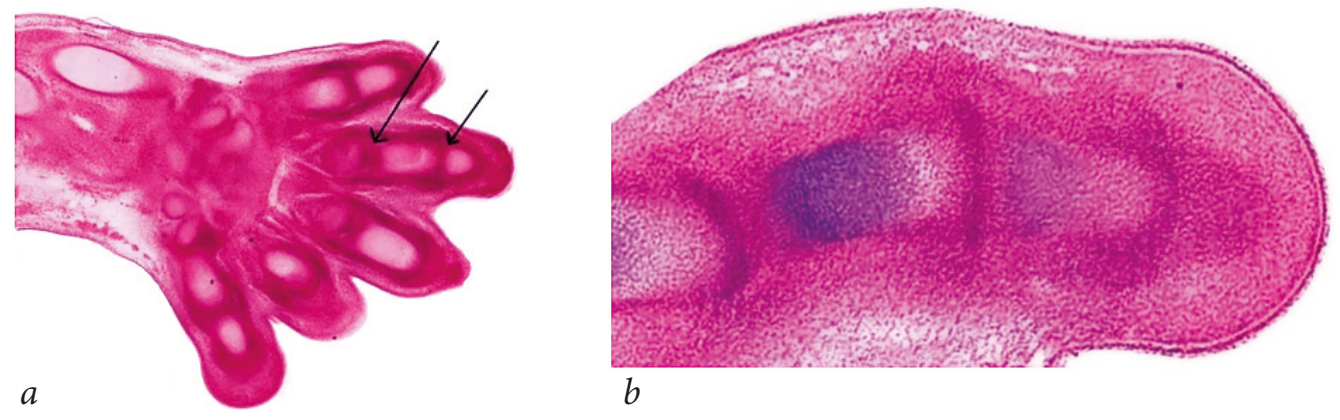

Figure 1: $a$ - Frontal section of fetal hand at 7 weeks. Left arrow: developing metacarpophalangeal (MCP) joint; right arrow: developing proximal interphalangeal (PIP) joint; $b-$ Fetal finger at 7,5 weeks. Left to right: developing MCP-, PIP-, and DIP- (= distal interphalangeal) joints

In the same way, transversal slices of late fetal fingers are currently considered as being the equivalents of the corresponding sections of normal adult fingers [9; 12-15]. Meanwhile, the extensor assembly of the human finger, composed of extensor tendon fiber bundles, is often depicted as consisting of single lines [16]. In reality however, its medial bundle and lateral bundles consist of three-dimensional tendinous slips [16] (see figs. $2 a, 2 b$ ).

\section{Research question and hypothesis}

Palmar gliding of the lateral bundles during PIP flexion implies the changing of their positions with respect to orthogonal planes, moving namely from a frontal plane to a sagittal plane [17]. Such anatomical findings, however, are based on in-vitro anatomical observations of interphalangeal flexion of the finger in lateral views, elucidated by means of transversal slices of the PIP joint in extension (see figs. $3 a, 3 b$ ) and flexion [17; 18]. 


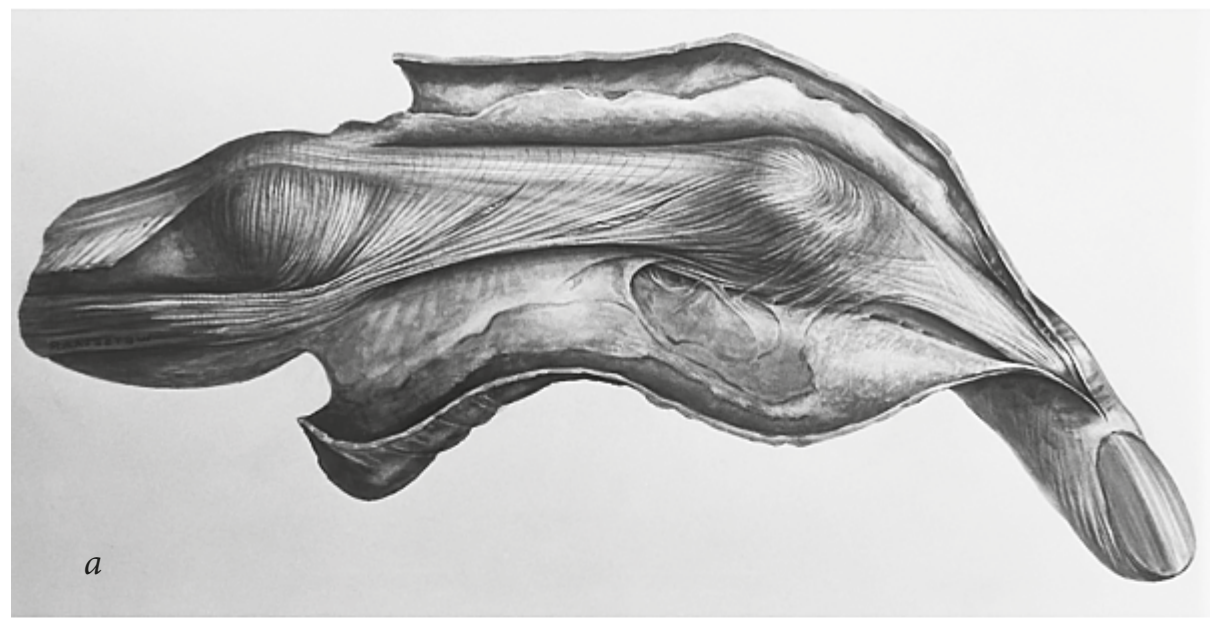

$b$
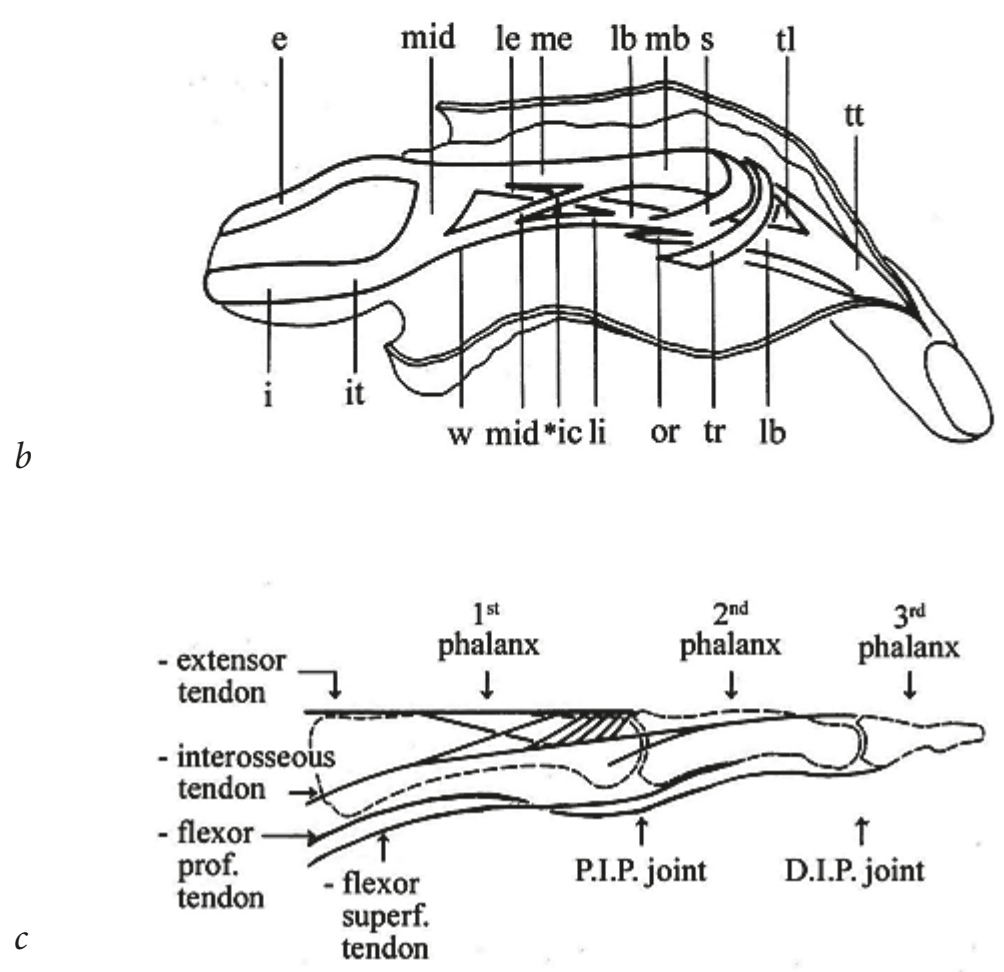

Figure 2: $a-$ Halftone drawing, anatomical specimen extended right $3^{\text {rd }}$ finger in situ, ulnar view, structures explained below; $b$ - Line drawing. e, long extensor tendon; i, dorsal interosseus muscle; it, interosseus tendon; mid, medial interosseus fibers, dorsal layer; w, wing tendon; le, lateral part, long

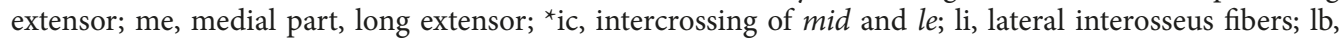
lateral bundle; $\mathrm{mb}$, medial bundle; s, spiral fibers; or, oblique retinacular ligament; $\mathrm{tr}$, transverse retinacular ligament; $\mathrm{tl}$, triangular ligament; $\mathrm{tt}$, terminal tendon; $c$ - Diagram of finger phalanges (dotted lines) and interphalangeal joints, lines of all finger tendons superimposed 

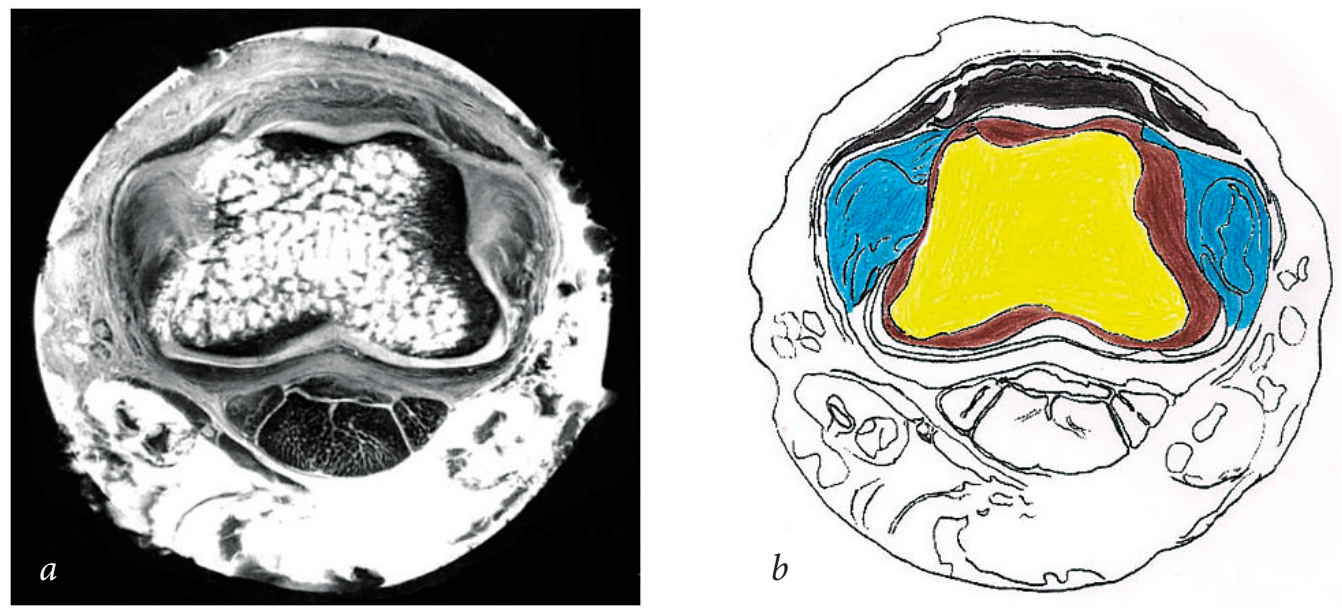

Figure 3: $a-$ HR-MRI of intact anatomical specimen of a right third finger in full extension, transverse slice at the level of proximal interphalangeal (PIP) joint. Structures relevant for the present study are indicated in Fig. 3b and below; $b$ - Outline of trochlea of proximal phalanx plus soft tissues at PIP-jointlevel. Black, medial bundle and lateral bundles (note their spindle-forms); yellow, bone marrow; brown, bone cortex; blue, PIP joint collateral ligaments

Bony structures in these slices can be compared with their osteology in distal view, especially with regard to the caput or head of the first phalanx, also known as the trochlea of the proximal interphalangeal joint (see figs. $4 a-c$ ).

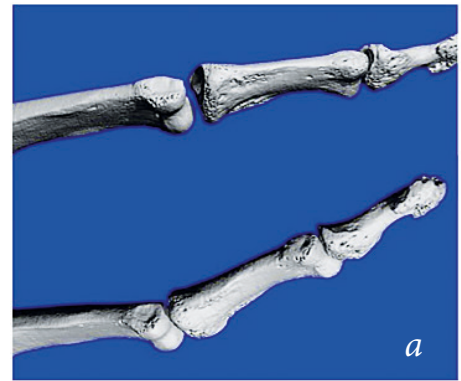

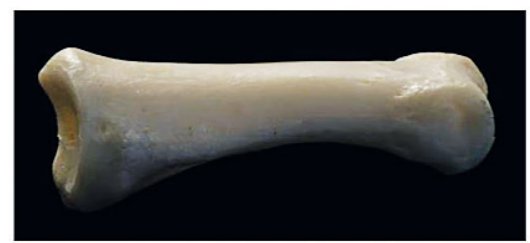

$b$

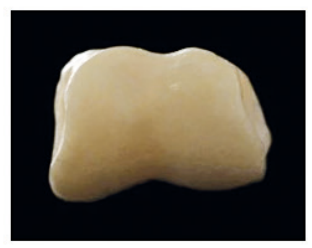

$c$

Figure 4: $a-3 \mathrm{D}$ images osteology PIP-joint and DIP-joint, left index finger, combined palmar, lateral, and proximal views; $b$ - Photomacrograph of the proximal phalanx of the left index finger, lateral view. At the right, both condyles of the caput (or trochlea) of the proximal phalanx are clearly visible; $c$ - Caput (or trochlea) of proximal phalanx left index finger, seen from distally, showing its 'shoulders', cf. Fig. 3

In-vivo data that may confirm or reject these in-vitro observations remain scarce [2; $3 ; 19]$. Therefore, our research question is: to what extent do the lateral bundles change their positions in-vivo during interphalangeal flexion with respect to orthogonal planes. Our hypothesis is hereby that actual in-vivo events are reflected by their in-vitro events.

\section{Material and methods}

High-resolution ultrasonography was applied on normal healthy PIP joints (male 57 years; female 21 years) during PIP extension and flexion in this order: 1 . finger in ex- 
tension, 2. flexion of PIP joint only, and 3. flexion of DIP joint while PIP joint is already flexed [20]. It should be noted that, following tutorial instructions [21], the starting position of the extended finger had to be stretched, and is so slightly different from what is generally known as the "functional" or "departure" position of the hand and the fingers [22; 23]. Ultrasonography was performed using a Philips iU 22 linear probe, $17 \mathrm{MHz}$ and 5-14 MHz with a water-based ultrasound gel. We checked these in-vivo positions in otherwise healthy adult fingers.

"The extensor tendons are thin hypoechoic slips on ultrasound. Distally this may be difficult to see" [21, video article]. Our aim at capturing the ultrasound transversal images at PIP joint level in vivo was such, that these could be compared with the corresponding HR-MRI in-vitro slices of the adult normal PIP joint in order to test our hypothesis [18; $24 ; 25]$.

The high resolution-MR imaging (HR-MRI) of a normal anatomical specimen of the PIP-joint of an extended right third finger [37] was performed in three orthogonal planes by a Varian 400 spectrometer with a 9,4 T superconducting magnet. The field of view FOV $(\mathrm{mm})$ in the transverse plane was $25 \times 25$ and with an imaging data matrix of $350 \times 350$, this resulted in a pixel resolution $(\mu \mathrm{m})$ of $71 \times 71$. Further acquisition parameters were: repetition time $\mathrm{TR}=2500 \mathrm{~ms}$; echo time $\mathrm{TE}=18 \mathrm{~ms}$; number of averages $\mathrm{NA}=24$; slice thickness $2 \mathrm{~mm}$.

\section{Results}

With respect to the PIP joint of the finger in extension, it should be noted that in HRMRI it becomes clear that the lateral bundles do not rest on bony structures but mainly on the in extension relaxed proper collateral ligaments (PCL) of the joint $[6 ; 17 ; 18 ; 27-29]$ (see figs. $3 a, b, 5 a$ ). This relaxation causes the PCL to undulate, bulging laterally $[25 ; 30]$ (see fig. $5 b$ ).
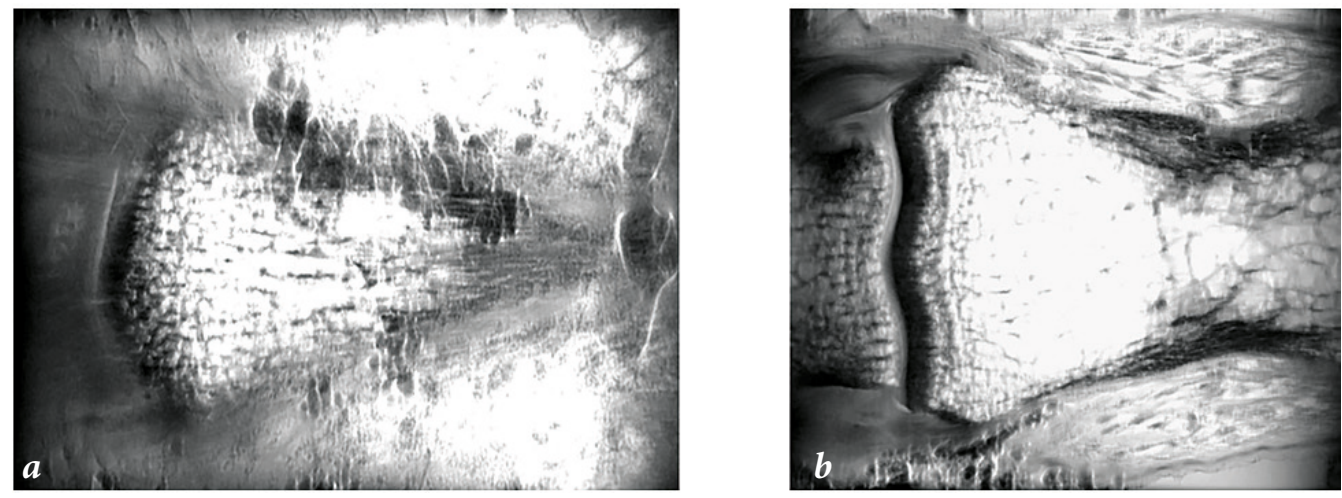

Figure 5: $a-$ HR-MRI of intact anatomical specimen of a right third finger in full extension, frontal slice at the level of proximal interphalangeal (PIP) joint (at the left). Both lateral bundles of extensor assembly, visible as converging streaks, are fusing into the terminal tendon for the distal interphalangeal (DIP) joint. Compare with Figure 2; $b-$ HR-MRI, somewhat deeper than Fig. 5a. At the left, relaxed PIP collateral ligaments are seen to bulge out 

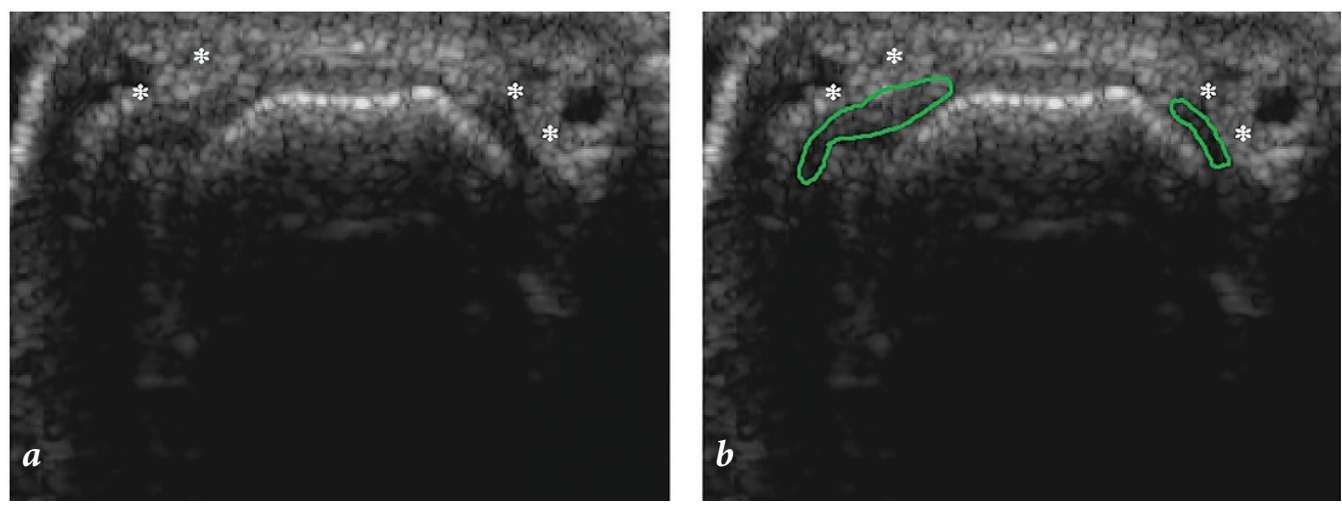

Figure 6. In-vivo HR-US right $3^{\text {rd }}$ finger, extension, PIP joint, male 57 yrs. ${ }^{*}{ }^{*}$ indicate hypoechoic lateral bundles: $a$ - Positions of lateral bundles in extension relative to trochlea comparable to transversal slice in Fig. 2; $b$ - Same image as Fig. 6a, outlines of the lateral bundles are indicated, quite comparable to Fig. 2. $c$ - Only the outline of the right lateral bundle from Fig. $6 \mathrm{~b}$ has been selected, and represented as its silhouette (green). The red line indicates its slant position, situated between frontal and sagittal planes

In case of PIP flexion this undulating bulge is smoothened out in consequence of straightening of the proper collateral ligaments, letting them appear longer $[6 ; 31]$.

We observe a satisfying congruence between the transverse images acquired by HRMRI and by HR-ultrasonography [6], confirming our hypothesis in this case. The lateral bundles of the extensor assembly are located in a plane which itself is situated between frontal and sagittal planes, running along the trochlea of the PIP joint (see figs. $6 a-c$, $7 a, b)$.
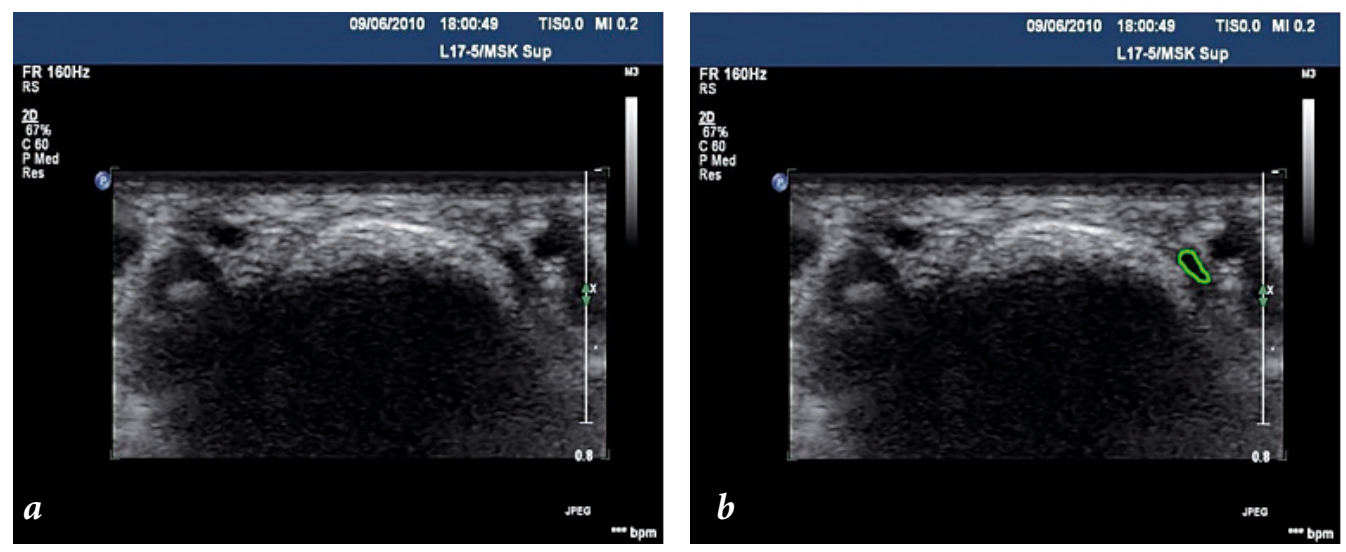

Figure 7: $a$ - In-vivo HR-US right third finger in full extension, PIP joint, female 21 yrs., quite comparable to Fig. $6 \mathrm{a} ; b-$ The same image as Fig. $7 b$. At the right, the outline of one of the lateral bundles is indicated in green

Ultrasonography of PIP flexion without DIP flexion shows that the lateral bundles lose their support by the PCL and displace in a palmar direction. Thereby in transversal view the lateral bundles apparently "topple over" ("tip over the edge") towards sagittal planes, however, assuming only slightly more palmar positions than in extension (see figs. $8 a, b)$. 


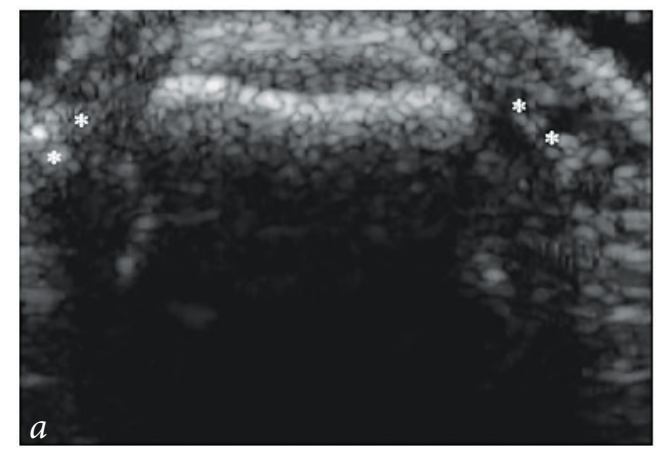

$b$
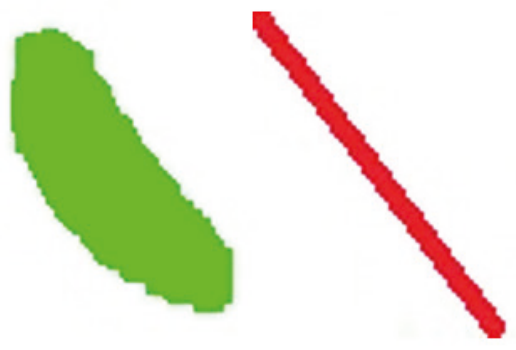

Figure 8: $a-$ In-vivo HR-US of right third finger, male 57 yrs., full PIP flexion only; ${ }^{*}$ indicate the lateral bundles; $b$ - Only the outline of the right lateral bundle from Fig. 8a has been selected, and represented as its silhouette in green. Red line indicates its position, situated somewhat more towards a sagittal plane than in full extension

During subsequent DIP flexion, in transversal ultrasonographic view lateral bundles of the extensor assembly are seen to topple much further, until they have reached quite tilted positions along the trochlea of the flexed PIP joint. Hereby they assume almost sagittal, and as a consequence, more palmar positions along this trochlea (see figs. $9 a, b$ ).
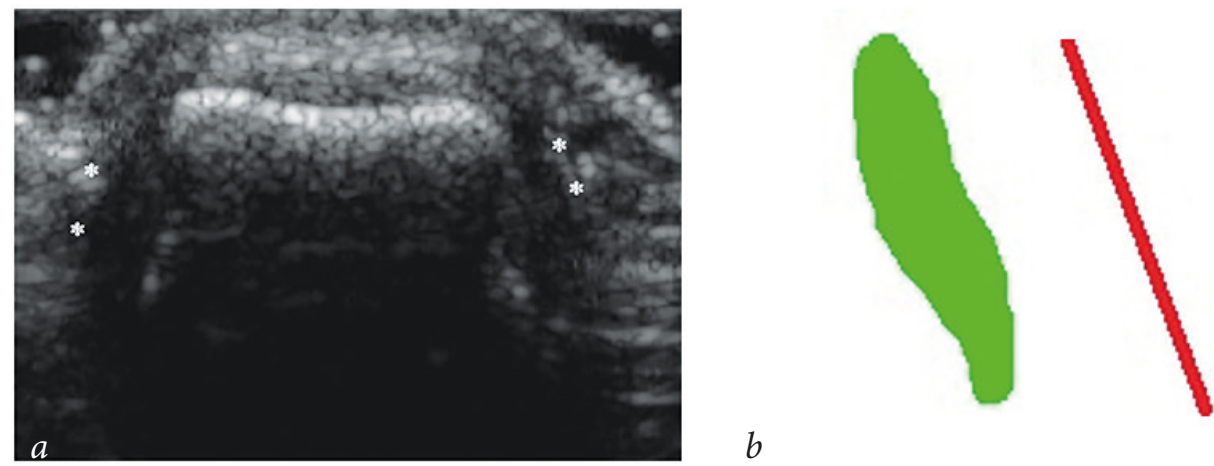

Figure 9: $a$ - In-vivo HR-US of right third finger at PIP joint level, male 57 yrs., in full PIP flexion combined with full DIP flexion. ${ }^{*}$ indicate the lateral bundles; $b$ - Only the outline of the right lateral bundle from Fig. $9 a$ has been selected, and represented as its silhouette in green. Red line indicates its location, which now is situated in an almost sagittal plane and therefore in a more palmar position with respect to the flexion axis of the PIP joint (see Fig. 10)

\section{Discussion}

According to Kuczinsky [30, p. 660], "the proximal attachment of the collateral ligament of the PIP joint is to the pit on the side of the head of the proximal phalanx" (see figs. $4 a, b$ ). This pit forms a depression on either lateral side of the head of the proximal phalanx, giving space to the PCL to fill this gap. In its turn, the PCL of the extended PIP joint, supports the lateral bundles proximally (see figs. $3 a, b$ ). In transversal section the trapezoidal head, also known as the trochlea of the proximal phalanx (see figs. $3 a, b$ ), contrasts with lower primates and their predecessors in which this section is more rectangular [23]. In man and higher primates, Landsmeer [32, p. 340] states that in PIP flexion 


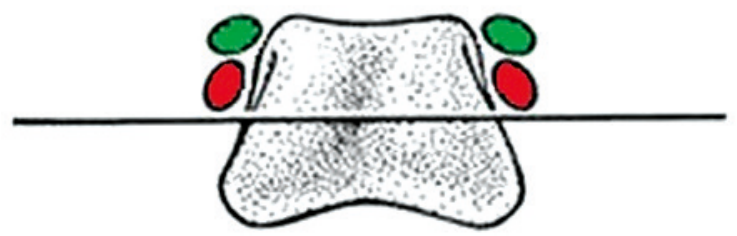

Figure 10. Positions of lateral bundles along the "shoulders" of the trochlea of the proximal interphalangeal (PIP) joint of the finger, in extension (lateral bundles in green) and full finger flexion (lateral bundles in red), with respect to PIP joint flexion axis. Normally, the lateral bundles never pass below this axis. Schematic representation after [24], based on [43]

the lateral bands "run along the shoulders of the trochlea" of the proximal interphalangeal joint. The "shoulders of the trochlea" [32, p. 340] come into view when the covering by the PCL shifts downward during PIP flexion [33,34]. These "shoulders" can also be seen in the osteological views (see figs. $4 b, c$ ).

Also with respect to the lateral slips or bands, Tubiana et al. [4, p. 102] state: “...these fiber bands glide along the posterolateral aspect of the joint during flexion movements..." The results of our pilot study confirm these above statements. The role of the spiral fibers of the extensor assembly of the finger during the palmar gliding of the lateral bands in PIP flexion in health and disease was also clearly demonstrated by Nigro [35]. Recently, Durand et al. [36] succeeded in performing reconstructive surgery of the spiral fibers.

While the in-vivo data about the precise positions of the tendinous lateral bundles (or lateral bands) of the extensor assembly of the human finger in proximal interphalangeal (PIP) flexion, prior to or simultaneous with distal interphalangeal (DIP) flexion, are remarkably scarce, we completed them by more precise details [19;21]. Our in-vitro HRMRI transverse slices of an extensor assembly of the finger in situ in full extension at PIPlevel match with in-vivo ultrasonography $[25 ; 37 ; 38]$. In both imaging techniques at this level namely, transverse slices of the lateral bundles of the extensor assembly show more or less spindle-like forms (see figs. 3a, 7b). The MRI-images in [25] also confirm our above findings that the proper collateral ligaments of the PIP joint support the lateral bundles in extension. Light-microscopy shows the same results [39; 40].

It should be noted that our hypothesis is confirmed only with respect to the extended finger, and the fully flexed finger as represented in Figure 2 of [41, p. 204] and Figures 5.16-5.18 of [13, pp. 191-192].

In-vitro data [42] suggest that the medial bundle and the lateral bundles of the extensor assembly are rather robust structures. Contrary to that, during in-vivo ultrasonography these bundles appear as thin hypoechoic slips, which distally may be difficult to see. Nevertheless, high resolution ultrasonography proves to be a suitable technique to unravel their displacements $[2 ; 3]$.

There is unanimity of opinion that normally, palmar gliding of the lateral bands of the extensor tendon never descends below the transverse axis of the PIP joint [24; 43] (see fig. 10) so as to prevent Boutonnière deformity $[35 ; 43]$. The present unravelling is quintessential in planning and performing finger extensor tendon repair and reconstruction techniques, e.g. after traumatic hand injuries $[1 ; 43]$. 


\section{References}

1. Li Y., Ding A., He Z., Xue F. Comparison of proximal turndown of central slip combined with suture of lateral bands versus free tendon grafting for central slip reconstruction after an open finger injury. Acta Orthop. Belg., 2014, vol. 80, no. 1, pp. 119-125.

2. Van Zwieten K. J., Thywissen C., Hotterbeekx A., Kosten L., De Munter S., de Bakker B. S., Varzin S. A., Piskun O.E., Zubova I. A., Schmidt K. P. Aspects of the extensor assembly of the finger during interphalangeal flexion. Proc. of the $178^{\text {th }}$ Scient. Meeting Dutch Anatomical Society (N.A. V.). Lunteren, 2016, pp. 27-28.

3. Van Zwieten K. J., Thywissen C., Hotterbeekx A., Kosten L., De Munter S., de Bakker B. S., Varzin S. A., Piskun O. E., Zubova I. A., Schmidt K. P. The extensor assembly of the human finger in interphalangeal flexion. Proc. of the tUL Life Sciences Research Day, Landcommanderij Alden Biesen. Bilzen, 2016, p. 54.

4. Tubiana R., Thomine J.-M., Mackin E. Examination of the hand and wrist. $2^{\text {nd }}$ ed. London, Martin Dunitz, 1996. 408 p.

5. Tubiana R. Rappel de l'anatomie de l'appareil extenseur des doigts au niveau de l'articulation interphalangienne proximale. Traité de Chirurgie de la Main, ed. R. Tubiana, t.3, Paris, Masson, 1986, pp. 125128.

6. Van Zwieten K.J., Lippens P.L., Gelan J., Adriaensens P., Thywissen C., Gens F. Observations in proximal interphalangeal flexion of the finger. Proc. of the $168^{\text {th }}$ Scient. Meeting Dutch Anatomical Society (N.A. V.). Lunteren, 2006, p. 10.

7. Van Zwieten K. J., Schmidt K.P., Bex G. J., Lippens P.L., Duyvendak W. An analytical expression for the DIP-PIP flexion interdependence in human fingers. Acta Bioeng. Biomech., 2017, vol. 17, no. 1, pp. 129-135.

8. Van Zwieten K. J., Schmidt K. P., De Munter S., Kosten L., Hotterbeekx A., Lippens P. L., Adriaensens P., Lambrichts I., Geusens P. Finger proximal inter phalangeal (P.I.P.) motion: joint surfaces and ligamentous geometries are interrelated. Proc. of $6^{\text {th }}$ Annual All-Russian Res. and Pract. Conf. with Intern. Particip. "Health - the Base of Human Potential: Problems and Ways to Solve Them". St. Petersburg, 2011, pp. 231-236.

9. Whillis J. The development of synovial joints. J. Anat., 1940. vol. 74, no. 2, pp. 277-283.

10. Decker R.S., Koyama E., Pacifici M. Genesis and morphogenesis of limb synovial joints and articular cartilage. Matrix Biol., 2014, vol.39, pp.5-10.

11. Stricker S., Mundlos S. Mechanisms of digit formation: human malformation syndromes tell the story. Dev. Dynam., 2011, vol.240, pp.990-1004.

12. Landsmeer J. M. F. Ruimtelijk verband in het polsgebied. Neth. J. Med., 1969, vol.113, no. 15, pp.681682.

13. Landsmeer J. M. F. Atlas of Anatomy of the Hand. London, Churchill Livingstone, 1976. 362 p.

14. De Bakker B.S., De Jong K.H., Hagoort J., Oostra R.-J., Moorman A. F. M. Towards a 3-dimensional atlas of the developing human embryo: The Amsterdam experience. Reprod. Toxicol, 2012, vol.34, pp. 225-236.

15. De Bakker B. S., De Jong K. H., Hagoort J., De Bree K., Besselink C. T., De Kanter F. E. C., Veldhuis T., Bais B., Schildmeijer R., Ruijter J.M., Oostra R.-J., Christoffels V.M., Moorman A. F. M. An interactive three-dimensional digital atlas and quantitative database of human development. Science, 2016, vol.354, no. 6315, pp. aag0053-1-aag0053-8.

16. Van Zwieten K. J., Lippens P. L., Thywissen C., Duyvendak W. Coordination of interphalangeal flexion in the human finger. Proc. of the $169^{\text {th }}$ Scient. Meeting, Dutch Anat. Soc. (N. A. V.). Lunteren, 2007, p. 10.

17. Van Zwieten K. J., Lippens P. L., Gelan J., Adriaensens P., Schmidt K. P., Thywissen C., Duyvendak W. Coordination of interphalangeal flexion in the human finger. J.Hand Surg. Brit.-Eur., 2008, vol.33, no. 1, pp. 170-171.

18. Van Zwieten K. J., Lippens P. L. Some factors influencing 3-D modeling of the human finger. Proc. $11^{\text {th }}$ Bruss. Intern. Symp. Adv. in Anatomy and Clinical Examination of the Hand and Wrist. Brussels, 2003, p. 48.

19. Van Zwieten K. J. Ultrasound techniques used in functional morphological hand research, BioMed Institute and Jessa Hospital, University of Hasselt, Belgium. ISVD, 2011, vol. 12, no. 3, item 7-1.

20. Van Zwieten K. J., Potekhin V. V., Lippens P. L., Sholukha V. A., Zinkovsky A. V. The influence of finger position on percussion sounds: CD-ROM. Proc. $13^{\text {th }}$ Intern. Congr. on Sound and Vibration (ICSV13). Vienna, 2006.

21. Allison S. J. Musculoskeletal Ultrasound: Evaluation of the Finger. Am. J. Roentgenol., 2011, vol. 196, no. 3, p. W308. 
22. Landsmeer J. M. F., Bos K. E. Videotape "The extensor assembly of the human finger, structure and function". Amsterdam, 1991. (C) Audiovisual Centre, University of Amsterdam.

23. Aterkar V., Sanghvi U., Sethi K. A novel inexpensive technique to immobilize open hand injuries in a functional position using a premolded light-weight external fixator. IJISR, 2015, vol. 4, no. 3, pp. 096099.

24. Van Zwieten K. J., Hotterbeekx A., Pouydebat E., Schmidt K. P., Helder P., Lippens P. L. Some functional-anatomical characteristics of finger movements in the hands of human and other primates. Proc. of $8^{\text {th }}$ Annual All-Russian Res. and Pract. Conf. with Intern. Particip. "Health - the Base of Human Potential: Problems and Ways to Solve Them". St. Petersburg, 2013, pp. 518-528.

25. Lewis A. R., Nolan M. J., Hodgson R. J., Benjamin M., Ralphs J. R., Archer C. W., Tyler J. A., Hall L. D. High resolution magnetic resonance imaging of the proximal interphalangeal joints. J.Hand Surg. Brit.-Eur., 1996, vol.21B, no. 4, pp. 488-495.

26. Lippens P. L., Adriaensens P., van Zwieten K. J., Gelan J., De Moor O. High resolution MRI of flexor and extensor tendons in the human finger. J. Morph., 1997, vol. 232, no. 3, pp. 287-287.

27. Kanavel A. B. Infections of the Hand. $4^{\text {th }}$ ed. Philadelphia; New York, Lea and Febiger, 1921. 516 p.

28. Lee S. A., Kim B.H., Kim S.J., Kim J.N., Park S. Y., Choi K. Current status of ultrasonography of the finger. Ultrasonography, 2016, vol. 35, no. 2, pp. 110-123.

29. Bakri K., Carlsen B.T., Moran S. L. Ligament injuries of the hand and wrist. Grabb and Smith's Plastic Surgery. $7^{\text {th }}$ ed. Wolters Kluwer Health Adis (ESP), 2013, pp. 817-832.

30. Kuczinsky K. The proximal interphalangeal joint. J. Bone Joint Surg. Br., 1968, vol. 50B, no. 3, pp. 656663.

31. Sandhu S.S., Dreckmann S., Binhammer P.A. Change in the collateral and accessory collateral ligament lengths of the proximal interphalangeal joint using cadaveric model three-dimensional laser scanning. J. Hand Surg. Eur., vol. 41E, no. 4, pp. 380-385.

32. Landsmeer J.M.F. The extensor assembly in two species of opossum, Philander opossum and Didelphis marsupialis. J. Morph., 1979, vol. 161, no. 3, pp. 337-345.

33. van Zwieten K. J., De Bakker B. S., Struys, T., Kosten L., De Munter S., Hotterbeekx A., Lambrichts I., Adriaensens P., Schmidt K. P., Helder P. C., Lippens P. L. Enkele anatomische structuren in menselijke vingergewrichten die een rol zouden kunnen spelen bij de pathogenese van reumatoïde artritis. Nederlands Tijdschrift voor Reumatologie, 2015, vol. 15, no. 2, pp. 58-62.

34. van Zwieten K. J., Kosten L., De Munter S., Varzin S. A., Piskun O. E., Adriaensens P., Schmidt K.P., Lippens P.L. Het normale proximale interphalangeale gewricht van de vinger - enkele anatomische observaties. Nederlands Tijdschrift voor Reumatologie, 2017, vol. 17, no.3, pp.56-59.

35. Nigro R.O. Reconstrucción del aparato extensor de los cuatro últimos dedos. Consideraciones anatomoquirúrgicas sobre las estructuras de contención y de desliziamento. Rev. Asoc. Argent. Ortop. Traumatol., 2007, vol.72, pp. 55-62.

36. Durand S., Gaujoux G., Macquillan A. Triggering of the lateral slip of the extensor mechanism on a Bouchard's node. J. Hand. Surg. Eur., 2011, vol.36, no. 4, pp. 340-341.

37. Pokanati S.D. Boutteniere Deformity // Radshare. 2012. Available at: http://radfacts.blogspot. be/2012/07/boutennaires-deformity.html (accessed: 03.10. 2017).

38. Geertsma T.S. A. Central slip rupture causing a Boutonniere deformity // Ultrasound Cases, Musculo Skeletal Joints and Tendons. 6.4: Fingers. 2015. Available at: http://www.ultrasoundcases.info/TestYourself-Case. aspx?test $=8420 \&$ cat $=370 \&$ group $=68 \&$ page $=0 \&$ show $=1$ (accessed: 03.10 .2017 ).

39. Chikenji T., Suzuki D., Fujimiya M., Moriya T., Tsubota S. Distribution of nerve endings in the human proximal interphalangeal joint and surrounding structures. J.Hand. Surg., 2010, vol.35A, pp. 12861293.

40. Wang X., Chamberland D.L., Jamadar D.A. Noninvasive photoacoustic tomography of human peripheral joints toward diagnosis of inflammatory arthritis. Opt. Lett., 2007, vol. 32, no. 20, pp. 30023004 .

41. Landsmeer J. M. F., van Zwieten K. J. Observations on the extensor assembly in some primate species. J. Anat., 1974, vol. 117, no. 1, pp. 204-205.

42. Qian K., Traylor K., Lee S. W., Ellis B., Weiss J., Kamper D. Mechanical properties vary for different regions of the finger extensor apparatus. J. Biomech., 2014, vol.47, no. 12, pp. 3094-3099.

43. Thompson J. S., Peimer C. A. Extensor tendon injuries: acute repair and late reconstruction. Chapman's Orthopaedic Surgery. $3^{\text {rd }}$ ed. Philadelphia, Lippincott, Williams \& Wilkins, 2001, chapter 49. 
Author's information:

van Zwieten Koos Jaap - MD, PhD, Professor; koosjaap.vanzwieten@uhasselt.be

Thywissen Carlo - MD; carlo.thywissen@jessazh.be

HotterbeekxAn - PhD; an.hotterbeekx@uantwerpen.be

Kosten Lauren _ MSc; lauren.kosten@uantwerpen.be

de Munter Stephanie - PhD; stephanie.demunter@gmail.com

de Bakker Bernadette - MD, PhD; b.s.debakker@amc.uva.nl

Adriaensens Peter — PhD, Professor; peter.adriaensens@uhasselt.be

Varzin Sergey A. - MD, Associate Professor; drvarzin@mail.ru

Piskun Oleg E. — PhD, Associate Professor; piskunoe@imop.ru

Schmidt Klaus P. — PhD, Professor; klaus.schmidt@uhasselt.be

\title{
Боковые разгибатели скольжения (боковые пучки) пальца руки при сгибании в межфаланговом сочленении
}

\author{
К. Я.ван Цвиетен ${ }^{1}$ Ц. Тайвиссен ${ }^{2}$, А. Хоттербикс ${ }^{1}$, Л. Костен ${ }^{1}$, С. де Мунтер ${ }^{1}$,

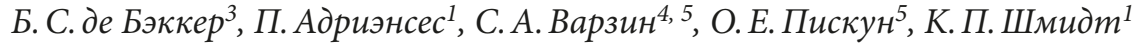 \\ 1 Университет г. Хасселта, Бельгия, В 3590, Диепенбек, ул. Агоралэн, стр. D \\ 2 Джесса госпиталь, Бельгия, В 3500, Хасселт, Стадсомфарт, 11 \\ 3 Университет Амстердама, Нидерланды, $1105 \mathrm{AZ}$, Амстердам, ул. Майбергдриф, 15 \\ ${ }^{4}$ Санкт-Петербургский государственный университет, Российская Федерация, 199034, Санкт- \\ Петербург, Университетская наб., 7-9 \\ ${ }^{5}$ Санкт-Петербургский политехнический университет Петра Великого, Российская Федерация, \\ 195251, Санкт-Петербург, Россия, ул. Политехническая, 29
}

Для цитирования: van Zwieten K. J., Thywissen C., Hotterbeekx A., Kosten L., de Munter S., de Bakker B. S., Adriaensens P., Varzin S. A., Piskun O. E., Schmidt K. P. The lateral extensor slips (lateral bundles) of the human finger in interphalangeal flexion // Вестник Санкт-Петербургского университета. Медицина. 2018. Т. 13. Вып. 1. С. 46-57. https://doi.org/10.21638/11701/spbu11.2018.105

В статье рассматривается нормальное ладонное скольжение боковых пучков сухожилия сгибателя вдоль проксимального межфалангового сочленения. Тонко настроенные сухожильные спиральные волокна позволяют при ладонном их скольжении одновременно сгибать дистальное межфаланговое сочленение. Это характерно для невозмущенной кинематической связи движения пальца. Наблюдения в эксперименте на трупе при манипулировании анатомическими элементами пальца описывают данное явление. Однако подобные наблюдения на живом человеке до сих пор отсутствовали. Благодаря ультрасонографии высокого разрешения удалось наблюдать у живого человека в поперечном сечении проксимального межфалангового сустава, сочленении при разгибании, а также при сгибании ладонное скольжение боковых пучков. Полученные изображения использовались для сравнения с эквивалентными трансверсальными сечениями пальца на трупе и с существующими представлениями из литературы. Констатировано удовлетворительное соответствие между поперечными изображениями, полученными магнитно-резонансной томографией высокого разрешения и ультрасонографией высокого разрешения. При проксимальном межфаланговом сгибании боковые пучки занимают несколько большее ладонное положение, чем при разгибании. При дистальном межфаланговом сгибании боковые пучки принимают почти сагиттальные позиции и, как следствие, также оказываются в ладонной проекции по отношению к проксимальному межфаланговому сочленению. Полученные данные могут быть использованы в восстановлении сухожилия разгибателя пальца при реконструктивной хирургии. 
Ключевые слова: боковые разгибатели (боковые пучки) человеческого пальца, сгибание и разгибание межфалангового сустава, функциональная анатомия пальца, палец, кисть, межфаланговое сочленение, верхняя конечность, скольжение боковых пучков, магнитно-резонансная томография высокого разрешения, ультрасонография высокого разрешения.

Контактная информация:

ван Цвиетен Коос Яаап — MD, PhD, проф.; koosjaap.vanzwieten@uhasselt.be Тайвиссен Карло - д-р мед. наук; carlo.thywissen@jessazh.be ХоттербиксЭн-PhD; an.hotterbeekx@uantwerpen.be Костен Лаурен - MSc; lauren.kosten@uantwerpen.be де Мунтер Стефани — PhD; stephanie.demunter@gmail.com де Бэккер Бернадетте - MD, PhD; b.s.debakker@amc.uva.nl Адриэнсес Петер — PhD, проф.; peter.adriaensens@uhasselt.be Варзин Сергей Александрович - д-р мед. наук, доц.; drvarzin@mail.ru Пискун Олег Евгеньевич - канд. мед. наук, доц.; piskunoe@imop.ru Шмидт Клаус Петер - PhD, проф.; klaus.schmidt@uhasselt.be 